\title{
Environmental education for sustainable human and resource development in Nigeria
}

\author{
Alaba E. Dare \\ Department of Social Science Education, Faculty of Education, Kogi State University, \\ P.M.B. 1008, Anyigba, Kogi State, Nigeria \\ Phone: 08060052769 \\ E-mail address: exceldare@yahoo.com
}

\begin{abstract}
The natural environment of the $21^{\text {st }}$ century is facing the threat of global warming and climate change due to human interaction with the environment. This paper focused on environmental challenges in the Niger Delta and the impact of oil spillage on the Biodiversity of the wetland area of the zone. Appropriate Conservation and Sustainable approach were recommended, which include: Enforcement of environmental laws, cleansing of oil spill, restricting access to environmental resources and constant surveillance of our coastal areas and oil fields.
\end{abstract}

Keywords: natural environment; environmental education; Nigeria

\section{INTRODUCTION}

Environmental Education refers to organized efforts to teach about how natural environment function and particularly how human beings can manage their behavior and ecosystems in order to live sustainably. The term is often used to imply education within the school system, from primary to post - secondary. However, it is sometimes used more broadly to include all efforts to educate the public and other audience including print materials, websites, medial campaign etc.

Environmental education as Swan (1969) consented is learning processes that increase peoples' knowledge and awareness about the environment and associated challenges, develops the necessary skills and expertise to address the challenges and foster attitudes, motivations and commitments to make informed decision and take responsible action as (UNESCO: Tbilisi declaration 1978) emphasized certain concepts, principles and policy of this declaration focus of environmental education as follows:

* Awareness and sensitivity about the environment and environmental challenges.

* Knowledge and understanding about the environment and environmental challenges.

* Attitude concern for the environmental and help to maintain environmental quality.

* Skills to mitigate the environmental problems.

* Participation for exercising knowledge and environmental related programs.

Environmental education programs therefore seeks to first engage with participants through developing a sense of nature appreciation which is then translated into action that affect conservation and sustainability. 


\section{ENVIRONMENTAL SUSTAINABILITY}

Environmental sustainability involves making decision and taking action that are in the interest of protecting the natural world with particular emphasis on preserving the capability of the environment to support human life. Environmental sustainability is making responsible decision that will reduce your business negative impact on the environment it is not simply about reducing the amount of waste you produce or using less energy but is concerned with developing processes that will lead to business becoming completely sustainable in the future. Human activities can potentially cause damage to all areas of the environment, some of the common environmental concerns include:

* Damaging rainforests and woodland through logging and agriculture clearing.

* Polluting and over - fishing of oceans, rivers fossil fuels.

* Damaging prime agricultural and cultivated land through the use of unsustainable farming practice.

\section{NIGER DELTA}

The Delta covers, $20,000 \mathrm{~km}^{2}$ within wetland of $70,000 \mathrm{~km}^{2}$ formed by sediment deposition. Home to 20 million people and 40 different ethnic groups, this flood plain makes up $7.5 \%$ of Nigeria's total land mass. It is the largest wetland and maintain the third-largest drainage basin in African. The Deltas environment can be broken down into four ecological zones: coastal barrier islands, mangroves swamp forest, fresh water swamps, and lowland rainforests. This incredibly endowed ecosystem contains one of the highest concentrations of biodiversity on the planet, in addition to supporting abundant flora and fauna, arable terrain that can sustain wide variety of crops, lumber or agricultural trees and more species of freshwater fish than any ecosystem in West Africa.

However, the region is by far the record holder among environmental disaster zones of the world which can perharps be best encapsulated by a 1983 report issued by the NNPC. Long before popular unrest surfaced: We witnessed the slow poisoning of the waters of this country and the destruction of vegetation and agricultural land by oil spills which occur during petroleum operations. But since the inception of the oil industry in Nigeria, more than twenty five years ago, there has been no concerned and effective effort of the part of the government let alone the oil operators to control environmental problems associated with the industry.

\section{OIL SPILLS}

Extent of the problem: Nigeria has a total of 159 oil fields and 1481 wells in operation according to the ministry of petroleum resources. The most productive region of the nation is the coastal Niger Delta Basin in the Niger Delta or South-south region which encompasses 78 of the 159 oil fields.

The Department of Petroleum Resources estimated 1.89 million barrels of petroleum were spilled into the Niger Delta between 1979 and 1996 out of a total 2.4 million barrel spilled in 4,835 incidents (Daily independent 26 July, 2010) (approximately 220 thousand cubic metres) A UNDP report states that there have been a total of 6,817 oil spills between 1976 and 2001 which account for a loss of three million barrels of oil of which more than 70 $\%$ was not recovered (UNDP 2006) most of these spills occurred off-shore (69 \%) a quarter 
was in swamps and $6 \%$ spilled on land. Some are caused by sabotage and thieves, however most are due to poor maintenance by oil companies (shell).

The Nigerian National Petroleum Corporation places the quantity of petroleum jettisoned into the environment yearly at 2,300 cubic metres with an average of 300 individual spills annually (Browen 1999) However, because this amount does not take into account "minor" spills, the World Bank argues that the true quantity of petroleum spilled into the environment could be as much as ten times the officially claimed amount. The largest individual spills include the blowout of a Texaco offshore station which in 1980 dumped an estimated 400,000 barrels $\left(64,000 \mathrm{~m}^{3}\right)$ of crude oil into the Gulf of Guinea and Royal Dutch Shell's Forcados Terminal tank failure which produced a spillage estimated at 580,000 barrels $92,000 \mathrm{~cm}^{3}$ ( Nwilo \& Badejo 2001). In 2010 Baird reported that between 9 million and 13 million barrels have been spilled in Niger Delta since 1958 (Baird J. 2010).

\section{CAUSES}

Oil spills are common event in Nigeria and occur due to a number of causes including: corrosion of pipelines and tankers (accounting for $50 \%$ of all spills) sabotage (28\%) and oil production operations $(21 \%)$ with $1 \%$ of the spills being accounted by inadequate or nonfunctional production equipment. The largest contributor to the oil spill total, corrosion of pipes and tanks, is the rupturing or leaking of production infrastructures that are described as "very old and lack regular inspection and maintenance (Nwilo \& Badejo 2001). A reason that corrosion accounts for such a high percentage of all spills is that as a result of the small size of the oilfields in the Niger Delta, there is an extensive network of pipelines between the field, as well as numerous small network of flowline.

The narrow diameter pipes that carry oil from wellheads to flowstations allowing many opportunity for leaks. In onshore areas most pipeline and flowlines are laid above the ground. Pipelines which have an estimate life span of about fifteen years are old and susceptible to corrosion. Many of the pipelines are as old as twenty to twenty five years (Brownwen 1999). Even shell admits that most of the facilities were constructed between 1960s and early 1980 to the then prevailing standard (SPDC) Shell Petroleum and Development Company) would not build them that way today.

Sabotage is performed primarily through what is known as "bunkering" whereby the saboteur attempt to tap the pipeline. In the process of extraction, sometimes the pipeline is damage or destroyed, oil extracted in this manner can often be sold. Damaged lines may go unnoticed for days and repair of the damaged pipes takes even longer. Sabotage and theft contribute further to environmental degradation.

While the popularity of selling stolen oil increases, the number of deaths are increasing. In late December 2006 more than 200 people were killed in the Lagos region of Nigeria in an oil line explosion.

Nigerian regulations of the oil industry are weak and rarely enforced allowing in essence the industry to self regulate (Baird J.2010) 


\section{CONSEQUENCES}

Spills in populated areas often spread out over a wide area, destroying crops and agricultures through contamination of the groundwater and soil in agricultural communities, often a year supply of food can be destroyed instantaneously because of the careless nature of oil operation in the Niger Delta.

People in the affected area complain about health issues including breathing problems and skin diseases, many have lost basic human rights such as heath, access to food, clean water and in ability to work. Oil contamination affects the fish population and affects the farmers that rely on fishing to support their families

\section{1. Theories and Examples}

Central to Hardin's article is an example (first sketched in an 1833 pamphlet by William Foster Lloyd) involving medieval land tenure in Europe of herders sharing a common parcel of land on which they are

Each entitled to let their cows graze. In Hardin's example it is in each herders interest to put the next (and succeeding) cows he acquired onto the land even if the quality of the common is damage for all as a result through overgrazing. The herder receives all of the benefits from an additional cow, while the damage to the common is shared by the entire group. If all herders make this individually rational economic decision, the common will be depleted or even destroyed, to the detriment of all. Hardin also cited modern examples including the overfishing of the worlds oceans and ranchers who graze their cattle on government lands in the American West.

\section{TRAGEDY OF THE COMMON}

The concept of the tragedy of the common is extremely important for understanding the degradation of our environment. The concept was clearly expressed for the first time by Garrett Harding in his famous article in science in 1968 which is widely accepted as a fundamental contribution to ecology population theory, economics and political science.

Harding University of Califonia santa Barbara.

\section{1.The basic Idea}

If a resource is held in common for use by all, then ultimately that resource will be destroyed freedom in a common brings ruin to all "to avoid the ultimate destruction, we must change our human values and ideas of morality."

1. Held in common means the resources in owned by no one, or owned by a group, all of whom have access to the resources.

2. Ultimately means after many years, maybe centuries. The time interval is closely tied to population increase of those who have access to the resources. The greater the number of people using a resource, the faster it is destroyed . thus the tragedy of the commons is directly tied to over population.

Hardin asks for strict management of common goods via increase government involvement or and international regulation. In addition, moral or ethic can lead to changes in use of the resources. How can this be done? Ostrom et all (1999) provide a possible answer "solving [commons] problems involves two distinct element. 
1. Restricting access and

2. Creating incentive [usually by assigning individual rights to or shares of the recourses for user to invest in the resource instead of overexploiting it.]

Both changes are needed for example, access to the north pacific Chalibut fishery was not restricted before the recent introduction of individual transferable quotal and catch limits protected the resources for decades, limiting access alone can fail if the resources users compete for share and the resources can become depleted unless incentive or regulations prevent over exploitation. For much of the past most business have acted with little regard or concern for the negative impact and somel organizations are guilty of significantly polluting the environment and engaging in practices that are simply not sustainable. Environmental impact assessments have remain a veritable tools in achieving environmental sustainability.

\section{WHAT IS EIA}

Environmental assessment (EA) and related procedures have been identified as key mechanisms used to translate the principles and criteria of sustainable development into practical strategies and actions. The 1992 conference on environment and development and agenda 21 put considerable emphasis on the potential ability of environmental assessment to achieve more sustainable form of development. As part of precautionary principles. Principles 17 of Rio declaration provides that an evaluation of environmental impact must be taken by virtue of a national instrument in regard to whatever proposed activity that probably produce a considerable negative impact on the environment since then, the use of environmental impact assessment (EIA) as a management tool for improving the long term viability of many projects and as an avoidance mechanism against incalculable mistakes that can be expensive and damaging in environmental and social economic terms, has increased tremendously.

Although, there appear to be no universally acceptable definition of EIA, it has generally been defined to meant the examination, analysis and assessment of planned activities with a view to ensuring environmentally sound and sustainable development, it is a process of identifying, predicting and evaluating the forcible impact of both beneficial and adverse alternatives and mitigating measures with a view also to eliminating or minimizing negative impact and optimizing positive impacts.

It is also a process of decision making and means of ensuring that the project options under consideration are environmentally and socially sound and sustainable. Statutorily, it is defined as an estimate or judgment of the significance and value of environmental effects for natural, socio - economic and human receptors.

By identifying and evaluating the probable environmental effect of a proposed activity, EIA seeks to prevent adverse one from occurring, elaborating available option and means for minimizing unavoidable effects. It works to balances a proposed activity's socio - economic benefits with its environmental cost, in this sense, EIA contributes to prevention of environmental damage in the first instance as well as prudent environmental management through the life of a development activity. It is also a means of gathering environmental information which ultimately serves to (a) inform government decision makers about environmental consideration they should take into account before authorizing a development activity (b) identify and analyse ways in which the benefits of an activity likely has adverse environmental effects and (c) ensure the sustainable management of natural resources and the prevention of environmental degradation and (d) identify and analyse reasonable alternatives to the proposed development projects that have no environmental impacts. 
Rather, the EIA process aims at finding the best project option, in both environmental and socio - economic terms, under the circumstance during its formative days, it was commonly viewed as concerning only impacts on the times, recognizing the utility of EIA, its horizons have broadened to incorporate a social impact assessment (SIA), environmental health assessment, risk assessment, strategic environmental assessment (SEA) and cumulative effects assessment.

\section{CONCLUSION}

The concept of sustainable national development can only be achieved through public private partnership participation. Conflict and policing will never solve problems of environmental challenges in Niger Delta. Various environmental laws should be enforced. The National Environmental Standard and Regulation Enforcement Agency should be more pro-active in sanctioning companies engaged in the degradation of the environment. By enforcing laws and holding oil companies accountable for their actions, the risk of contamination can be greatly reduce. Geographical information system (GIS) can be put to work to quickly identify and track spilled oil. To hasten the clean up of spills, regional cleanup sites along the problem areas could help contain spills more quickly. Constant monitoring and air surveillance of our coastal lands and oil fields. Limiting the numbers of oil company and oil field that are licensed and the use of quota system. This measure we go a long way in reducing negative impact of exploration and usage of natural resources.

\section{References}

[1] Baird J. (2010). Oil shame in Africa, Newsweek 27.

[2] Bronwen Manby (1999). The price of oil human right watch 1999.

[3] Diamond, J. 2005 collapse: How societies choose to fail or succeed, Viking

[4] Hardin Garret., Science 162 (1969) 1243-1248.

[5] Harding G., Science 280(5364) (1998) 682-683.

[6] Ostrom E. J., Burger et.al., Global challenges science 281(5412) (1999) 278-282.

[7] Swan J. A (1969 September). The Challenges of Environmental Education phi Delta Kappan 51: 26-28. The Belgrade charter, Adopted by the UNESCO - UNEP International Environmental workshop October 13-22, 1975.

[8] UNESCO - Tbilisi Declaration 1978.

[9] Maffat and Linden (1995). Perception and Reality: Assessing Priorities for Sustainable Development in the Niger River Delta.

[10] Niger Delta development report UNDP 2006 P. 76.

[11] Nwilo and Badejo (2001). Impact of oil spill along the Nigerian coast. The Association for Environmental Health and Sciences 2001. 
[12] The daily independence (Lagos). 2010 shell and the \#15bn oil spill judgment debt 07-19.

[13] Shell International Petroleum Company Developments in Nigeria (London: March 1995).

[14] Vida John (2010). Nigeria agony dwarfs the Gulf oil spill.

( Received 04 October 2013; accepted 20 October 2013 ) 